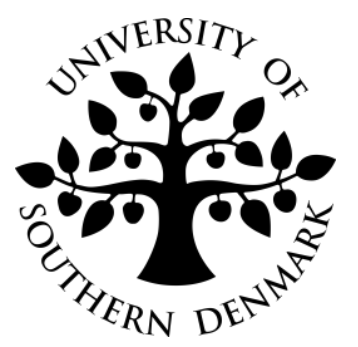

\title{
Housing equity, residential mobility and commuting
}

\author{
by
}

Gintautas Bloze and Morten Skak

Discussion Papers on Business and Economics

No. 16/2015

FURTHER INFORMATION

Department of Business and Economics Faculty of Business and Social Sciences University of Southern Denmark Campusvej 55, DK-5230 Odense M

Denmark 


\title{
Housing equity, residential mobility and commuting
}

\author{
Gintautas Bloze ${ }^{*}$ and Morten Skak**
}

\begin{abstract}
Highly productive economies require a flexible labor force with workers that move in accordance with the changing demand for goods and services. In times with falling housing prices, home owning workers' mobility may be hampered by a lock-in effect from low and negative equity. This paper explores the effect of housing equity on homeowners' residential mobility and their commuting pattern. We merge administrative registers for the Danish population and properties and get highly reliable micro data for our analysis. We compare the lock-in of homeowners with high LTV ratios under a booming economy with the lock-in when the economy is in recession. Low and negative equity reduces residential mobility, with similar relative effects in boom and slump periods. The negative impact on labor market flexibility from low equity lock-in is stronger when the economy is in recession and housing prices are falling. We show that this is mitigated by a comparatively high propensity to commute for locked-in homeowners when the labor market tightens.
\end{abstract}

JEL classification: G21, J61, R23, R51

Keywords: Mobility, Commuting, LTV ratio, Home equity, Mortgage lock-in

\footnotetext{
* Correspondence Address: Gintautas Bloze, Department of Leadership and Corporate Strategy, University of Southern Denmark, Sdr. Stationsvej 28, DK-4200, Slagelse, Denmark. Email: gbl@sdu.dk

**Department of Business and Economics, University of Southern Denmark, Campusvej 55

DK-5230 Odense M, Denmark, E-mail: mos@sam.sdu.dk
} 


\section{Introduction}

A flexible labor market requires mobile workers that moves in accordance with demand. The moves can be between different types of working places within an area, between different types of jobs within firms and between working places in different areas. The last often requires geographical mobility beyond commuting. It is a well-established observation in the empirical literature that homeowners move less than renters, and Oswald (1996) conjectured a positive relation between a country's unemployment rate and the rate of homeownership. While Nickell (1998) was unable to confirm this analyzing labor markets in OECD countries, Oswald's relation was confirmed for US data by Green and Hendershott (2000) for the middle age (35-64) classes. Green and Hendershott reckoned that homeowners may self-select as person with high preferences for longer housing spells. If so, homeowners may compensate for this through a high probability to find and keep local jobs. Van Leuvensteijn and Koning (2004) find stronger job commitment for Dutch homeowners, but also high jobto-job mobility. A strong preference for local jobs may give homeowners low reservation wages compared to tenants. On the other hand if homeowners have longer employment spells, employers may invest more in their training and pay higher wages. Munch et al. (2006 and 2008) find a negative correlation between Danish homeownership and the risk of unemployment and a positive correlation between homeownership and the wage level.

Even though the relation between homeownership and the productive capacity of an economy may not be unilaterally negative it seems that factors that temporarily make it more costly for homeowners to move will increase the gap between the actual and the potential output. One such factor could be a negative development of housing prices that reduces equity and brings some households under water. The association between the loan-to-value (LTV) ratios of homeowners and their mobility is the first subject of this study. Reduced labor market flexibility for homeowners that are locked-in because of low equity could be mitigated by an increase of their mobility through more commuting. This is the second subject of the study.

We use micro data from Danish administrative registers. This allows us to sort out the most important family and job related changes that are the decisive factors behind many moves. An important difference compared to earlier studies is that we merge persons into households as the economic unit. The home values that we use are tax appraisal values for each home corrected by local sales price appraisal rates (the SPAR method). Our analysis is confined to households who do not own other real estate than their home. This and data on the household's debt backed by housing collateral enables us to calculate reliable LTV ratios for the households. Our moves are based on registered changes of the address of the persons involved. We define a move as a shift of address for all the persons in a household.

Equity locked-in homeowners may increase their labor market mobility by commuting. To our knowledge this aspect has not been included in earlier studies. Our registers contain information on the persons' working place, which allows us to include commuting as an alternative option to moving. The head of the household is defined as commuting when the workplace is in a municipality different from the residential. 
The data construction gives us more than half a million observations of households units. We have chosen to present cross section analyses covering moves over the two years 2005 and 2009, with the preceding years used to detect changes in the households' environment. This enables a comparison of the correlations between mobility, commuting and housing equity and other variables between two points in the business cycle. The Danish economy was booming in 2005 with an unemployment rate below 4 percent and in recession in 2009 with 7.5 percent unemployment ${ }^{1}$. An analysis of panel data with year fixed effects to capture the impact of the business cycle as done in some the earlier studies seems less suited to reveal differences of the association between household specific elements and the mobility in different economic climates. In addition to logistics regressions on the whole sample, we exploit a natural experiment setting on restricted samples of homeowners with similar predicted propensity to move (commute) in 2005 that are randomly exposed to different LTV ratios in 2009.

Our results confirm the negative relation between homeowners' LTV ratio and their mobility found by other authors. Furthermore, the odds ratios in the two economic climates are fairly similar. We find no effect from nominal loss aversion (instrumented by nominal price decreases) and homeowner mobility. Overall, there is no significant difference between homeowners' and tenants' propensity to commute; and homeowners with high LTV ratios are not commuting significantly more than others when the economy is booming and labor demand is strong. However, high LTV ratios induce homeowners to commute significantly more when the economy is slumping.

The paper is organized as follows: Section two gives an overview of earlier economic studies on home equity and mobility, and section three describes the Danish housing market and the special Danish mortgage system together with a brief overview of the economic development. Section four has the econometric model and section five the data. After this section six gives the results of four logit regressions on moves by households in the two years 2005 and 2009 while section seven has the result of regressions from natural experiment designs. Section eight has the same analyses, but now for commuting, while section nine presents an analysis of the joint decision on moving and commuting. Finally, conclusions are drawn in section ten.

\section{Literature review}

The very steep increase of housing prices in many countries up till 2007 gave an upswing in economic research that focused on the affordability of housing and homeownership. In line with this, the first issue of the journal Housing Studies in 2007 was focused on International Perspectives on Planning and Affordable Housing. Affordability under steeply rising house prices can be a problem especially for young first time buyers and may thus reduce mobility. Nielsen and Jensen (2011) have studied this for Denmark and find that rising housing prices do not seem to impact on the trading volume. As can be seen in figure 1, the trading level remained on a high level during the price increases over the years after 1993, but started to decline just before the climax of prices in 2007 . Judged by this, affordability does

${ }^{1}$ OECD harmonized unemployment rates. 
not seem to have influenced trading negatively, while a lock-in effect from falling housing prices after 2007 apparently has been much more important. We restrict the following survey to studies on the relation between housing equity and mobility and further exclude the strand of literature that sees default as the exercise of a put option. This option is irrelevant for the Danish case as Danish mortgages are of full recourse loans. A chronological overview of earlier empirical papers is followed by some words on what is new in our study.

Figure 1: Real housing prices, trading volume and the percentage movers and commuters $1980-2013$

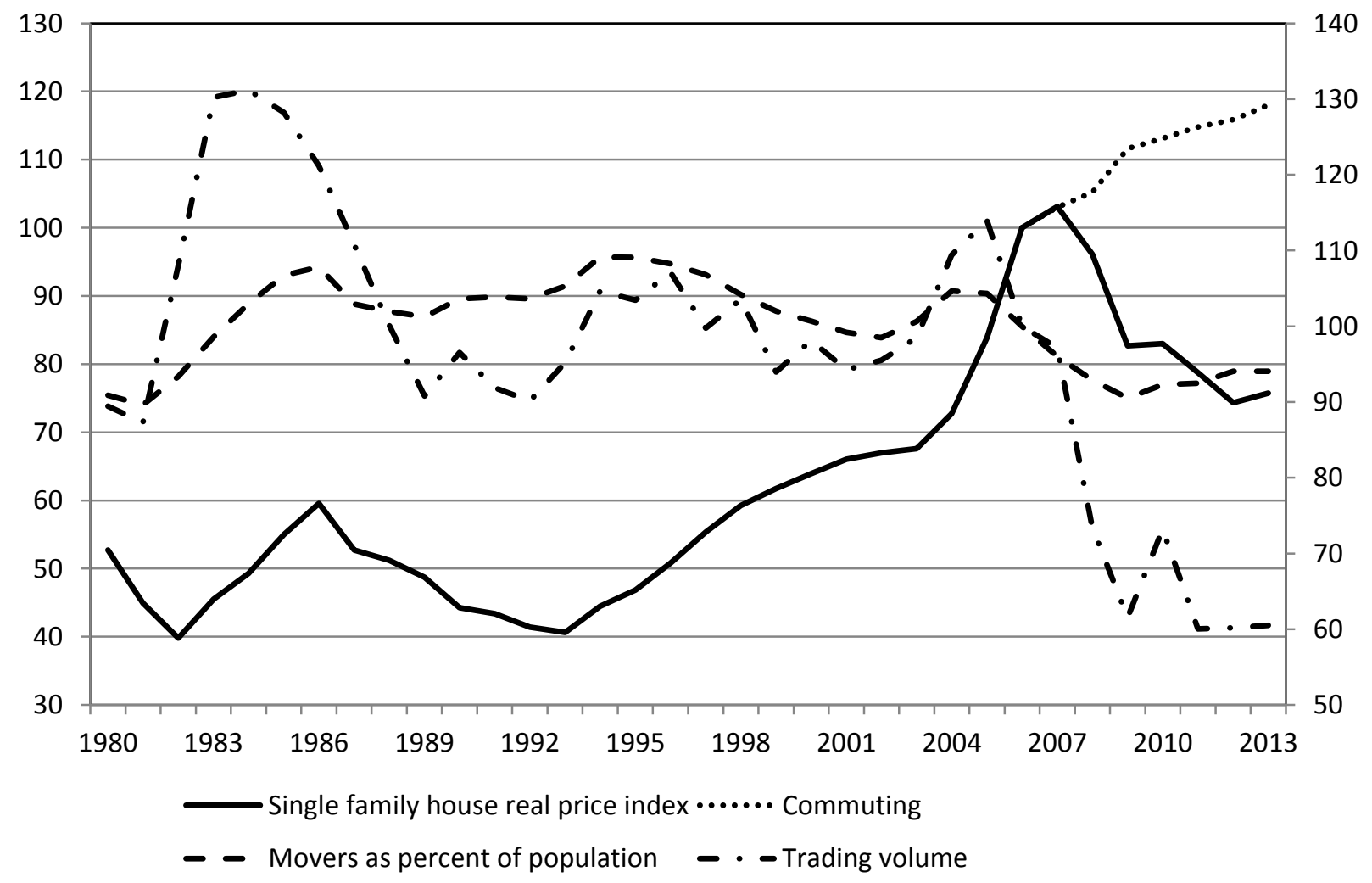

Notes: Left scale: The price index is Statistic Denmark's SPAR price index for single family houses deflated by the consumer price index. The number of persons (not only household heads) commuting between municipalities and having a distance of $20 \mathrm{~km}$ and more as per cent of all working commuting and non-commuting persons (only over the years 2006 to 2013). Right scale: The number of persons who change registered address per January first in two consecutive years as a percent of the population January first of the first year. The annual number of traded single family houses in ordinary sales as used by Statistic Denmark for the calculation of the price index. All series are indexed with $2006=100$.

Source: Statistic Denmark

Henley (1998) uses four waves of the British Household Panel Survey 1991-94 and applies a duration model to the data. He has a number of family related control variables, but does not include the usual mobility triggers of changes of the family variables. Besides this, variables on house characteristics and the employment situation are included. Regressions are done for homeowners and moving can be split 
into moving into ownership, into public sector rental, and into private sector rental. Housing equity is captured by three variables for outright ownership, the amount of equity in $f$, and negative equity. Henley finds significant negative relations between the LTV ratio and mobility, but weaker for movement into public rental. He presents a figure that shows the highest propensity to move when the amount of equity is positive but small.

Chan (2001) conducts an investigation based on data from verified mortgage application forms from the Chemical Bank in New York, New Jersey, and Connecticut. The years covered are 1989 to 1993. Because moves are defined as the end of a mortgage and conversion of mortgages are likely when interest rates fall, she restricts the sample to adjustable interest rate mortgages. Furthermore, her data does not capture moves by the lender when the house is unsold and rented out. This restricts the validity of her study. She applies a repeat sales index on county level to calculate variations in the LTV ratio over the years and estimates a duration model for housing spells. Her data allow her to control for sex, marriage, children and education, besides income and liquid assets. The initial LTV ratio and mortgage-points are used to reveal the households' innate mobility. Chan's results show a significantly negative relation between the propensity to move and the LTV ratio. Entering no change in housing prices in her model leads her to state that the mobility rate would have been one third higher after four years with no decline of housing prices.

Engelhardt (2003) uses data for young household over the years 1985 to 1996 . The LTV ratio is based on self-reported home values, but because of errors in this he instruments variations in the LTV ratio by the variation in metropolitan appreciation rates measured by the Freddie/Fannie indices. Engelhardt only considers moves from ownership into new ownership. He is able to include a number of family related mobility triggers and wants to distinguish between the effect of low equity due to falling housing prices and the effect of nominal price loss aversion on mobility. Inspired by Chan (2001) he conjectures that the LTV ratio at the time of purchase of the home captures differences in the households' innate mobility. Judged by the estimation results, a high initial LTV ratio is most binding and therefore should be preferred by households with high expected duration. Control for the initial LTV ratio is also important for the detection of the effect of nominal loss aversion. The mobility of households with low initial LTV ratio is affected by loss aversion and not by a lock-in effect because of low or negative equity. Tacking this into account in the regression design, Engelhardt concludes that there is a clear negative effect on mobility from nominal loss aversion, while no such effect is found from equity lock-in due to falling prices.

Data from the American Housing Survey 1985 to 2007 is used by Ferreira et al. (2010). The use of national data (for metropolitan areas) should give better reliability of the estimation results compared to the results from the studies by Chan (2001) and Engelhardt (2003). Movements are from ownership into ownership. Ferreira et al. have all the conventional variables thought to influence mobility. One special variable comes from the households' rating of their neighborhood. Financial variables and so the LTV ratio all rely on self-reported values. This leads Ferreira et al. to construct instrumental variables 
that combine self-reported initial entities with general price and interest rate developments ${ }^{2}$. New, compared to earlier studies is that Ferreira et al. include a fixed-rate mortgage lock-in effect. Because mortgages not are assumable, moving under increased interest rates incur bigger loan payments for unchanged annual owned housing consumption in a new location and this will hamper mobility. A negative effect on mobility from this is confirmed by their estimates. The estimated mobility reducing effect of negative equity is as large as or larger than previously estimated. Having negative equity reduces the mobility rate by four percentage points.

Donovan and Schnure (2011) focus on whether or not moves are intra-county or inter-county. With intra-county moves being less job related compared to inter-county moves, a lock-in effect from falling housing prices that only hits intra-county moves is not considered harmful to the country's productivity. Their analysis is not based on micro data, but data from the American Community Survey 2007 to 2009 with the counties being the statistical units. Donovan and Schnure regress the In of the share of the population that moves out of a given county on housing price changes, county control variables and state and year fixed effects. Overall, the results show a negative relation between falling hosing prices and mobility, and a comparatively bigger negative coefficient for intra-county than for inter-county moves. But the relation turns around for inter-state moves and this leads the authors to conclude that the lock-in effect due to underwater mortgages does not impede the efficiency of the job market.

Schulhofer-Wohl (2012) uses the same data as Ferreira et al. (2010) but includes moves out of ownership ${ }^{3}$. This gives a result opposite to Ferreira et al. (2010), namely that negative equity increases mobility. The result is explained by US homeowners in being able to default on their mortgage, leave the home and retain their other assets. This option leads to high mobility among owners with high negative equity.

Interviews from the British Household Panel Study over the years 1991 to 2008 is used by Ermisch and Washbrook (2012). The data allows for the ordinary family change mobility triggers, but Ermisch and Washbrook abstain from the use of divorce and child bearing as explanatory variables because they consider those to be endogenous. With self-reported data, current equity is instrumented with sales volume in the household's local authority area, while house prices are average market prices at the local authority level. The analysis is confined to households with women aged below 45 years, not living with their parents and being owners of a single home with a mortgage. 427 women are observed with 3059 woman-years. The panel data are regressed with fixed effects and in-person variation of the variables, which is seen as an advantage compared to cross section with between-person variations. Comparison shows that cross section coefficients on housing equity are low because of a negative relation between a person's equity ratio and her idiosyncratic propensity to move. Like in most other studies, the found relation between equity and mobility is negative.

\footnotetext{
${ }^{2}$ Ferreira et al. (2010) also includes a variable applicable to California because of its proposition 13.

${ }^{3}$ The American Housing Survey excludes houses that are vacant or rented according to Schulhofer-Wohl (2012), but having access to the raw data opens for a coding where houses that are vacant or rented out are coded as a move of the previous owner.
} 
Seko et al. (2012) construct panel data from six waves of the Japanese household longitudinal data. The years covered are 2004 to 2008. In Japan, loans are no-recourse, but the borrower must surrender any unencumbered assets to cover the loan. Thus, the Japanese system is midway between the American no-recourse and the European full-recourse system. It leads Seko et al. to construct an extended LTV ratio where savings and securities are subtracted from the outstanding mortgage debt. The extended debt is also used for the calculation of an extended debt-to-income ratio. Seko et al. study own-to-own moves and employ a fixed effect logit model. A number of household, housing and labor market characteristics are used as controls. The results show that negative equity correlates with reduced propensity to move and the same is the case for high debt-to-income ratios.

Coulson and Grieco (2013) use the 1999-2009 Panel Survey of Income Dynamics and rely on selfreported home values and LTV ratios. They claim that this is the relevant variable when homeowners (household heads) decide whether or not to move. The data enable the authors to include the typical family related mobility affecting variables and to distinguish between intra-state and inter-state moves, with state fixed effects to control for variance in state specific conditions. A multinomial model with three options: stay, move intra-state, and move inter-state is used. The results show higher mobility for under water mortgages than for over water mortgages and this is more pronounced for inter-state mobility. Based on this, the authors conclude that high LTV ratios do not reduce labor market mobility.

Modestino \& Dennet (2013) focus on US state-to-state migration and analyze data from the Internal Revenue Service over the period 2006 - 2009. According to the Current Population Survey, between 40 to 50 per cent of the inter-state moves are job related. Modestino \& Dennet use the share of nonprime households experiencing negative equity and the change in house prices as proxies to capture the variance in negative equity across states and over time. Unlike earlier studies, Modestino \& Dennet model what may be termed a full migration model, where inter-state migration is explained by differences in amenities between the states, i.e. differences in labor market conditions, per capita incomes, housing affordability, population age, ethnicity, climate etc., all measured at the state level. To this is added the aforementioned proxy for negative equity in each state. One problem is that also renters migrate between states and the results could be driven by moving renters. Robustness checks are made to cope with this potential problem. Their results show, like in earlier studies, that negative equity hampers the mobility. However, the effect is small. A one-standard deviation increase in the share of underwater nonprime households reduces the aggregate state-to-state migration rate by 0.05 percentage points.

The recent study by Andersson and Mayock (2014) is based on micro data that overcome a number of limitations of the previously used micro data sets. While former studies with self-reported property values have relied on instruments for negative or low equity, Andersson and Mayock use Florida Department of Revenue's appraised market values of the properties and merge this with transaction data from DataQuick. A move is defined as ownership change of a property. Randomly drawn credit bureau data on persons is then merged with properties with a statistical matching algorithm. Provided the algorithm is well functioning, reliable LTV ratios for homeowners can be constructed. Besides this 
they know the time since the previous purchase of the property and the age of the person, but do not have the conventional family based mobility triggers. The database covers Florida in the period 1999 to 2011. Andersson and Mayock distinguish between voluntary and involuntary moves and classify a move as involuntary if the household is in default on the mortgage at the time the ownership changes. Using a logit regression they find a strong negative relation between the LTV ratio for voluntary moves and a positive relation for involuntary moves.

In our study we use micro data covering all Danish citizens and properties. All persons and properties have identity numbers and we know the identity of the owners of each property. Property values are based on tax authorities' appraised values corrected by SPAR index price developments. From the administrative tax registers we have information on the persons' mortgage debt, which we use for the calculation of the LTV ratios for each home owning household. Our registers also contain information about family relations, residence and working location, tenure length etc. Our moves are based on registered changes of the addresses of the persons involved. We define a move as a shift of address for all the persons in a household. A move does not always imply that the home is sold. Another advantage of our study compared to earlier work is the ability to use tenants' mobility as reference. With data on commuting, we bring a new dimension into homeowner mobility. If there is a lock-in effect for homeowners because of high LTV ratios when housing prices are falling, this may to some degree be neutralized by an increase in commuting rates.

An aspect that to our knowledge do not seem to have been included in earlier work is changing banking behavior. Over the business cycle, banks can change their behavior against potential borrowers with equal economic robustness, and this may have positive or negative effects on homeowners' mobility. Such changes may well covariate with variations in housing prices and LTV ratios and blur our results. We do not study this in this paper, but leave it for future research.

\section{Overview of the Danish housing market}

Slightly more than half of the Danish homes are occupied by the owner. This rate has remained fairly constant for a long time, contrary to the development in most other European countries where an increase in the homeownership rate took place in the first decade of the 2000s.

After a bottom in 1993, house prices ${ }^{4}$ went on a long and steadily increasing path (see figure 1 ), which turned into a very steep increase after 2005. However, the bubble busted in 2007 and prices fell dramatically over the next two years. A slight recovery in 2010 was followed by yet another fall in 2011. A new turning point seems to have occurred at the entrance of 2012 and a recovery now seems under way. Prices for single family houses are today 16 per cent below the peak level in $2007^{5}$.

\footnotetext{
${ }^{4}$ The described development is based on the SPAR price index published by Statistics Denmark.

${ }^{5}$ Twenty six per cent in real terms.
} 
The Danish krone has been fixed to the euro since its introduction, which means that Danish interest rates follow ECB rates with a possible deviation depending on the investors' confidence in the krone and the reliability of the various bodies that issue krone denominated bonds. The result has been a long lasting decreasing trend in Danish nominal interest rates for mortgage bonds, but with peaks in 2000 (the dot com bubble) and 2008 (the financial crises). With the recent financial turmoil in southern European countries, Danish interest rates have fallen to unprecedented levels, see figure 2.

\section{The Danish mortgage system}

Danish first time homebuyers typically take all the loans they can with the real estate as collateral. Loans issued by the mortgage banks carry the lowest interest rate and are most attractive. The law limits such mortgage loans to 80 per cent of the appraised value of the property. These loans typically have first priority in the collateral. The homebuyers can borrow additionally in commercial banks with or without the property as collateral. Both commercial banks and mortgage banks look at the economic situation of the household and base the size of offered loans both on the appraised (future) value of the collateral and on the estimated ability of the household to pay future interests and installments in accordance with the type of loan.

Danish mortgage banks hold a one to one funding of the loans issued to homeowners. This means that mortgage bonds are issued with the payment obligations of the borrower. This may be a 30 year bond carrying an interest rate of say 4 per cent. The price of the bond in the market gives the revenue available to the borrower. The installments paid by the borrowers are used to randomly full repayment of the sold bonds in a series. When the mortgage carry a floating interest rate, bonds with one (two, three or five) years maturity are sold in the market and the resulting interest rate is transferred to the borrower.

The high availability of loans against possible free equity in the home has placed Danish households among the most indebted in the OECD. But Danish household have comparatively high assets in financial papers, labor market pensions and annuities besides the property values and this places Danish households in an average position when measured by net wealth.

Mortgage loans with a floating (low) interest rate have becoming increasingly popular after the turn of the century. Interest only mortgage debt was introduced in 2003 and has also grown in popularity since. Today more than half of the outstanding loans are interest only.

Since the downturn of house prices after 2007 a number of homeowners have houses that are "under water". It is estimated by Skak and Bloze (2013) that between one forth and one third of Danish homeowners are "over indebted" in the sense that the outstanding mortgage debt surpasses 80 per cent of the value of property. The share of homeowners with a LTV ratio above one is probably around 10 per cent. 
The mortgage bank will ask for a sale of the property if the owner fails to pay the scheduled payments on the loan. An ordinary sale is preferred, but eventually a foreclosure sale may be required. The now previous homeowner has a personal obligation to pay the mortgage bank the remaining debt in case the sales revenue does not cover the outstanding debt. The mortgage bank proposes a schedule for the repayment of the personal debt and has an interest in getting the best out of the circumstances. But the interest rate on the personal debt is higher and repayment conditions tougher so that owners do not voluntarily choose foreclosure. In general, the Danish recourse loan system makes it difficult to move for Danish households that are under water.

Default on the mortgage and foreclosure is often caused by unemployment, illness and divorces. Movements caused by foreclosure can thus be expected to be positively correlated with the unemployment rate, see figure 2 .

Figure 2: Mortgage interest rates, the unemployment rate and the number of foreclosures

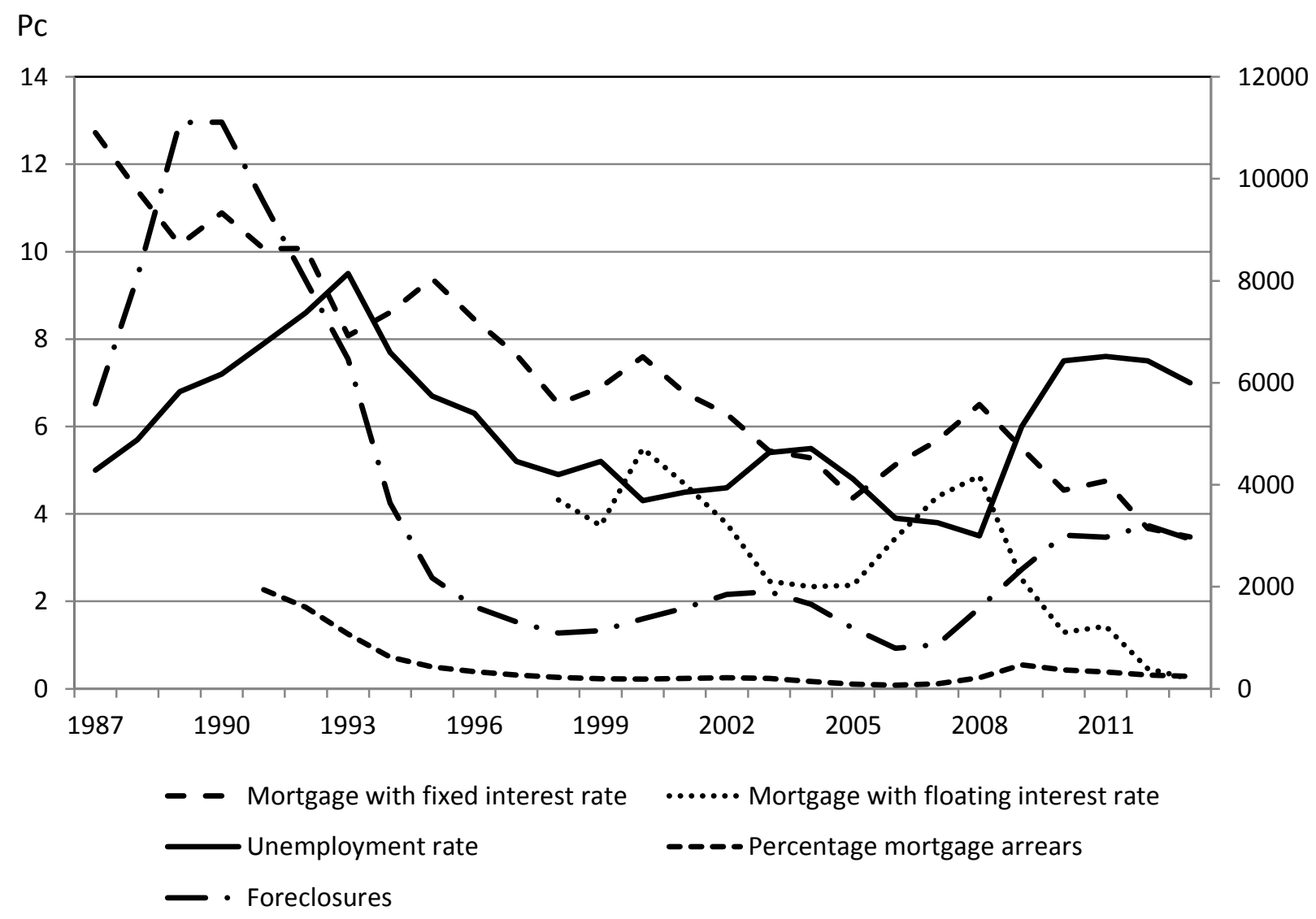

Notes: Left scale: The fixed interest rate is the rate for mortgage credit with 30 years maturity with fixed interest. The floating interest rate is an average for mortgage credit funded by bonds of one and two years' maturity. The unemployment rate is the OECD's harmonized unemployment rate. The percentage mortgage arrear is the annual average of the percentage of payments due each quarter that is not paid. Right scale: The annual number of foreclosures of single family houses.

Sources: Statistic Denmark, Danmarks Nationalbank and the Association of Danish Mortgage Banks 
The major reason behind the modest upswing in the number of foreclosures and mortgage arrears under the recent economic recession is the introduction and now widespread use of interest only and floating interest rate mortgage loans. This has been used by many households to convert existing fixed interest loans with repayment to floating interest only loans to obtain an important reduction of their quarterly payments.

\section{Econometric model}

Our strategy is to use cross section analyses for two years and compare how various factors are associated with mobility under an economic upturn and downturn respectively.

To illustrate our thoughts, assume that a household has three mobility options: stay, stay and commute, and move. Each option yields different levels of welfare: $U_{j}$ with $j=12$ and $3 . U_{j}$ is assumed to covariate with a number of individual and housing characteristics, including the LTV ratio for homeowners:

$$
U_{i j}=X_{i} \beta_{j}+\varepsilon_{i j}
$$

The subscript $i$ is households or observations, which in our case includes information on family characteristics, housing and financial characteristics. Households maximize utility and the probability that it will choose one of the three options depends on the size of the variables in $X_{i}$.

A multinomial logit model seems appropriate for this approach and we use this model in section nine. A disadvantage of the multinomial model is however that the same $X_{i}$ variables or characteristics must be applied to all three choices. A probably better model could be to look at the choices as hierarchical or nested in the following way. First a decision is made whether or not to move. This decision is guided by the expected obtainable maximum utility of these two states. After this, the households who stay decide whether or not to commute to obtain maximum utility from stay and stay and commute. Two binomial logistic models will then be applied.

The first decision concerns whether or not to migrate to a new location. We do not observe the utilities $U$ directly, but when the utility from moving is largest, we will observe a change of location. As above, we have

$$
U_{i j t}=X_{i t} \beta_{j}+\varepsilon_{i j t}
$$

Where $X_{i j t}$ contains information on family-related, housing-related or job-related factors which are likely to influence a household's utility from a move. $\varepsilon_{i j t}$ is a random error term, that we assume has a logistic distribution. As mentioned above we do not observe the latent $U_{i j t}$ but if utility from moving is largest we will observe a move. Letting $M_{i j t}$ be a dummy taking the value 1 if a household moves and let $U_{i 3 t}$ be the utility with migration $(j=3)$, then 


$$
M_{i t}=\left\{\begin{array}{l}
1 \text { if } U_{i 3 t}>\operatorname{Max}\left\{U_{i 1 t}, U_{i 2 t}\right\} \\
0 \text { if } U_{i 3 t} \leq \operatorname{Max}\left\{U_{i 1 t}, U_{i 2 t}\right\}
\end{array}\right.
$$

Assuming that $\varepsilon_{i j t}$ is logistically distributed, we apply a logistic model:

$$
\operatorname{Pr}_{i j t}=\Lambda\left(X_{i t} \beta_{j}+\varepsilon_{i j t}\right)
$$

where $\Lambda$ is the cumulative logistic distribution, $P r_{i j t}$ is the probability that a household changes residence between period $t$ and the subsequent period $t+1$, and $X_{i t}$ contains information as described above, and for some variables includes changes between $t-1$ and $t$. Odds ratios are calculated as the exponent of the estimation results. An odds ratio compares the probability of two outcomes to determine what is more likely for given outcome. The hypothesis is that once the other factors are considered, there will be a significant negative relationship between the LTV ratio and the probability of movement.

The second decision, whether or not to commute follows the same reasoning as above except that $J$ now takes values from $j$ being 1 or 2 . The hypothesis is that there is a positive relation between the LTV ratio and the probability of commuting among homeowners who do not move.

\section{Data and measurement issues}

We use Danish annual administrative register data covering the years 2004, 2005, 2006 and 2008, 2009 and 2010. In order to get reliable LTV ratios, we focus on homeowners that only own one property in the year of movement and disregard homeowners who own secondary homes or properties rented out ${ }^{6}$. Furthermore, we restrict the sample to households that have household heads from 20 to 60 years of age. Also, we define a move as a situation where all the members of a household move jointly away from the location, and we classify a household head as commuting when the municipality of the working place differs from the municipality where the home is located.

\begin{tabular}{|c|c|}
\hline Variables & Definition \\
\hline \multicolumn{2}{|l|}{ Dependent variable: } \\
\hline $\begin{array}{l}\text { Moving } \\
\text { Commuting }\end{array}$ & $\begin{array}{l}1 \text { if household has moved away between } t \text { and } t+1,0 \text { otherwise } \\
1 \text { if the household head's working place is in a municipality different from the home } \\
\text { municipality, } 0 \text { otherwise }\end{array}$ \\
\hline \multicolumn{2}{|l|}{ Independent variables: } \\
\hline $\begin{array}{l}\text { LTV ratio } \\
\text { Change of housing prices }\end{array}$ & $\begin{array}{l}\text { Ratio of outstanding mortgage debt to the market value of the property } \\
\text { Pc. change over the year before the move at municipal level }\end{array}$ \\
\hline \multicolumn{2}{|l|}{ Family related variables: } \\
\hline $\begin{array}{l}\text { Household size } \\
\text { Increase in household size }\end{array}$ & $\begin{array}{l}\text { Number of individuals in the household at } \mathrm{t} \\
\text { Increase in household size between } \mathrm{t}-1 \text { and } \mathrm{t}\end{array}$ \\
\hline
\end{tabular}

Table 1: Definitions of the variables 
Decrease in household size Household's yearly income

At least 20per cent increase in income

At least 20per cent decrease in income

High non-housing LTV Household head characteristics:

Female

Age

Married

Single

Change to married

Change to single

Job related variables (for the household head)

Employed

Out of workforce

Change to employed

Change to unemployed

Commuting

Started to commute

Stopped commuting

No education

Short education

Medium education

Long education

Housing related variables:

Persons per room

Single family house

Farmhouse

Semi-detached house

Multi-family housing

City municipalities

Suburb municipalities

Rural municipalities

Remote municipalities

Tenants mobility rate

Tenants commuting rate

Owner
Decrease in household size between $\mathrm{t}-1$ and $\mathrm{t}$

Total disposable income of all members in the household described by quartile distribution of income

1 if households total disposable income increased by more than 20per cent between $\mathrm{t}$ and $\mathrm{t}-1,0$ otherwise

1 if households total disposable income decreased by more than 20per cent between $\mathrm{t}$ and $\mathrm{t}-1,0$ otherwise

1 if household's debt to banks (such as outstanding overdraft or loans) exceeds financial assets (excluding home's property value) by more than 50,000 DKK , 0 otherwise

Years since the longest living resident moved in

1 if female, 0 if male

Age of household head

1 if household head is married or in registered partnership, otherwise 0

1 if household head is single/divorced/widow, 0 otherwise

1 if household head got married or registered partnership, 0 otherwise

1 if household head is got divorced or became single, 0 otherwise

Notes: Changes are 2008 to 2009 in one of the two cross section regression. Changes are 2004 to 2005 in the other regression. 


\subsection{Housing Equity}

Our focus is on the households' equity as determinant of migration and commuting. For that purpose we construct the Loan-to-Value ratio (LTV) as the ratio of outstanding mortgage debt to the value of the property. As mentioned before, we disregard households that own secondary homes or rental properties and focus on households owning the residence that they live in. We have observations of appraisal values of each residential real estate in Denmark and make a correction of the latest appraised value of the property by use of the sales price appraisal ratio (SPAR) ${ }^{7}$. This comes close to the method used by Andersson and Mayock (2014). Using self-reported property values as done in a number of previous studies is dubious. Our own research using survey data from $2012^{8}$ show that there can be a considerable difference between self-reported values and sales prices.

\subsection{Other variables}

Definitions of the variables are described in Table 1 and descriptive statistics are presented in the appendix. We define variables either for the whole household or for the household head only ${ }^{9}$. The basis date is 1 January 2005 or 2009, so that movement is measured as occurring between 1 January 2005 (2009) and 1 January 2006 (2010). Some independent variables are calculated as changes between 2004 (2008) and 2005 (2009), thus further sample restriction is imposed: we look at households that lived at least one year in their residence. The conventional triggers of migration and commuting can be divided in to three main groups: housing related, family related or job related. To account for family related reasons we include the number of children in the household and the marital status of the household head. To account for job related reasons, we control for the employment status of the household head and the household head's commuting to work. Housing related reasons include number of square meters per adult person and tenure length of longest living person in the dwelling. The independent variables used vary between regressions.

${ }^{7}$ SPAR $=\frac{\frac{\sum_{i=1}^{n} \text { Price }_{i}}{n}}{\frac{\sum_{i=1}^{n} \text { Appraisal }_{i}}{n}}=\frac{\sum_{i=1}^{n} \text { Price }_{i}}{\sum_{i=1}^{n} \text { Appraisal }_{i}}$ where Price $_{i}$ denotes the transaction price for house $i$ in the current period and Apprisal $_{i}$ is the latest appraisal for house $i$. To get as close as possible to market value of the property we calculate SPAR on municipality level and separately for houses and apartments. Appraisals for residential real estate are made every second year in Denmark.

${ }^{8}$ A paper on this is under preparation.

${ }^{9}$ Potentially we have information on every member in the household, but our presumption is that the personal characteristics of the household head are most important for the decision on whether or not to move. This presumption is even stronger when it comes to commuting because our commuting variable refers to the household head's commuting. 
As explained in section 3 above, having an LTV ratio above 0.8 creates difficulties for Danish households who want to move to another location. The difficulties are caused by the limit upper limit for borrowing from mortgage banks, which is 80 per cent of the property value. Borrowing beyond that limit will be from banks and other sources with tougher borrowing conditions. The lock-in of the households becomes more severe when the LTV ratio increases and the homes eventually come under water. With full recourse on all loans, Danish households are unable to improve their situation if they leave the house or in case of a foreclosure. No mortgage bank can force a household to move as long as the payments on the debt are made as scheduled. We use $0.8,1$ and 1.2 as knot points for LTV ratios. In 2005, there were 3.7 per cent homeowners ${ }^{10}$ with an LTV-ratio above 1 , while in 2009 there were 14.2 per cent such homeowners. With regard to mobility, in 2005 around 5 per cent home owning households moved away from their dwelling, while in 2009 the number was 2 per cent. When it comes to commuting, 44 per cent of the working household heads in home owning households commuted in 2005, while the number was 47 per cent in 2009.

\section{Lock-in from high LTV ratios}

We begin with logit cross section regressions for migrations in the year 2009 with the results shown in Table 2. Odd ratios are reported in the columns numbered (1) to (4). Column (1) to (3) report results for owners alone and column (4) include tenants as reference. The table shows odd ratios for LTV intervals and housing price change besides a number of control variables.

With many observations, most odds ratios are significantly different from one. Most of the explanatory variables have the expected effects known from other empirical studies, but a few of the odd ratios are close to one and the variables of minor importance for mobility. The big positive drivers of mobility of owners are a change of the household size, a change to single, starting to commute, a high non-housing LTV ratio, and ownership of a semi-detached home. Among these, a high non-housing LTV ratio may be a proxy for a good credit score that gives easy access to new credit when the household moves. A strong negative correlation with mobility is found for the two high income quartiles, becoming employed, ownership of a farmhouse and a decreasing income.

Our main focus is on the impact of the LTV ratio or housing equity on homeowners' mobility. Across the columns in where the LTV ratio is included, the odd ratios tell us that high LTV ratios and hence low housing equity are associated with significantly lower propensities to move. It is also evident from column (4) that owners move significantly less than renters ${ }^{11}$.

With no municipalities having a positive housing price development from 2008 to 2009 we are unable to entangle the effect of a possible price loss aversion among homeowners. But column (2) shows no association between the size of price developments and the propensity to move. We have tried to mimic

\footnotetext{
${ }^{10}$ Homeowners with only one home

${ }^{11}$ There is a special locking-in effect on most tenants in older apartments because of the Danish rent control system. This has been studied by Munch and Svarer (2002).
} 
some of the interaction effect between price changes and LTV ratios done by Engelhardt (2003), but have been unable to detect an effect from nominal loss aversion. Column (3) in Table 2 covers homeowners with equity rates between 60 and 100 per cent, who should be free from lock-in effects from high LTV ratios. For these homeowners, no association between the nominal price loss and mobility is found.

Table 2: Logistic regression results for moving in the year 2009

\begin{tabular}{|c|c|c|c|c|}
\hline & $\begin{array}{c}\text { Only owners } \\
\text { (1) }\end{array}$ & $\begin{array}{c}\text { Price change } \\
\text { included } \\
(2) \\
\end{array}$ & $\begin{array}{c}\text { Only most solvent } \\
\text { owners } \\
\text { (3) }\end{array}$ & $\begin{array}{l}\text { Tenants as } \\
\text { reference } \\
\text { (4) }\end{array}$ \\
\hline \multicolumn{5}{|l|}{ Categorical LTV dummies: } \\
\hline Tenants (reference group for column 4) & & & & ref. \\
\hline$[0,0.39)$ (reference group for column $1+2)$ & ref. & ref. & & $\begin{array}{c}0.3261^{* * *} \\
(0.0122)\end{array}$ \\
\hline$[0.39,0.79)$ & $\begin{array}{c}0.9491 * * * \\
(0.0254)\end{array}$ & $\begin{array}{c}0.9476 * * \\
(0.0252)\end{array}$ & & $\begin{array}{c}0.2934 * * * \\
(0.0095)\end{array}$ \\
\hline$[0.8,0.99)$ & $\begin{array}{c}0.4923 * * * \\
(0.0211)\end{array}$ & $\begin{array}{c}0.4918^{* * *} \\
(0.0209)\end{array}$ & & $\begin{array}{c}0.1435^{* * *} \\
(0.0072)\end{array}$ \\
\hline$[1.0,1.19)$ & $\begin{array}{c}0.2369 * * * \\
(0.0153)\end{array}$ & $\begin{array}{c}0.2368 * * * \\
(0.0153)\end{array}$ & & $\begin{array}{c}0.0688 * * * \\
(0.0047)\end{array}$ \\
\hline$[1.2, \max )$ & $\begin{array}{c}0.2207^{* * *} \\
(0.0169)\end{array}$ & $\begin{array}{c}0.2205^{* * *} \\
(0.0172)\end{array}$ & & $\begin{array}{c}0.0618^{* * *} \\
(0.0052)\end{array}$ \\
\hline Price decreases less than 5 pc. & & ref. & ref. & \\
\hline Price decreases from 5 to $10 \mathrm{pc}$. & & $\begin{array}{c}0.9204 \\
(0.0485)\end{array}$ & $\begin{array}{c}0.9264 \\
(0.0796)\end{array}$ & \\
\hline Price decreases above 10 pc. & & $\begin{array}{c}0.9708 \\
(0.0962)\end{array}$ & $\begin{array}{c}0.8314 \\
(0.1019)\end{array}$ & \\
\hline \multicolumn{5}{|l|}{ Family related variables: } \\
\hline Household size & $\begin{array}{c}0.7117^{* * *} \\
(0.0146)\end{array}$ & $\begin{array}{c}0.7114^{* * *} \\
(0.0146)\end{array}$ & $\begin{array}{c}0.8985 * * * \\
(0.0370)\end{array}$ & $\begin{array}{c}0.6611^{* * *} \\
(0.0069)\end{array}$ \\
\hline Increase in household size & $\begin{array}{c}5.3117^{* * *} \\
(0.2699)\end{array}$ & $\begin{array}{c}5.3121 * * * \\
(0.2700)\end{array}$ & $\begin{array}{c}14.138^{* * *} \\
(1.4869)\end{array}$ & $\begin{array}{c}4.7980 * * * \\
(0.3112)\end{array}$ \\
\hline Decrease in household size & $\begin{array}{c}9.3413 * * * \\
(0.2370)\end{array}$ & $\begin{array}{c}9.3400^{* * *} \\
(0.2370)\end{array}$ & $\begin{array}{c}5.5074 * * * \\
(0.4231)\end{array}$ & $\begin{array}{c}6.1801 * * * \\
(0.2370)\end{array}$ \\
\hline 1 income quartile (reference group) & ref. & ref. & ref. & ref. \\
\hline 2 income quartile & $\begin{array}{c}0.8485^{* * *} \\
(0.0316)\end{array}$ & $\begin{array}{c}0.8487 * * * \\
(0.0315)\end{array}$ & $\begin{array}{c}0.7828 * * * \\
(0.0595)\end{array}$ & $\begin{array}{c}1.1281 * * * \\
(0.0236)\end{array}$ \\
\hline 3 income quartile & $\begin{array}{c}0.6094 * * * \\
(0.0317)\end{array}$ & $\begin{array}{c}0.6092^{* * *} \\
(0.0318)\end{array}$ & $\begin{array}{c}0.4136 * * * \\
(0.0407)\end{array}$ & $\begin{array}{l}1.1253^{* *} \\
(0.0560)\end{array}$ \\
\hline 4 income quartile & $\begin{array}{c}0.4997 * * * \\
(0.0282)\end{array}$ & $\begin{array}{c}0.5006^{* * *} \\
(0.0286)\end{array}$ & $\begin{array}{c}0.2824^{* * *} \\
(0.0303)\end{array}$ & $\begin{array}{l}1.1256^{*} \\
(0.0730)\end{array}$ \\
\hline Decrease in income & $\begin{array}{c}0.7315^{* * *} \\
(0.0282)\end{array}$ & $\begin{array}{c}0.7321^{* * *} \\
(0.0282)\end{array}$ & $\begin{array}{c}1.4679 * * * \\
(0.1233)\end{array}$ & $\begin{array}{c}0.6492 * * * \\
(0.0138)\end{array}$ \\
\hline Increase in income & $\begin{array}{c}1.2100 * * * \\
(0.0367)\end{array}$ & $\begin{array}{c}1.2164^{* * *} \\
(0.0365)\end{array}$ & $\begin{array}{c}1.0253 \\
(0.0748)\end{array}$ & $\begin{array}{c}1.1328 * * * \\
(0.0137)\end{array}$ \\
\hline High non-housing LTV & $\begin{array}{c}1.5126 * * * \\
(0.0377)\end{array}$ & $\begin{array}{c}1.5244 * * * \\
(0.0378)\end{array}$ & $\begin{array}{c}1.5106^{* * *} \\
(0.0720)\end{array}$ & $\begin{array}{c}1.2752 * * * \\
(0.0131)\end{array}$ \\
\hline Tenure length & $\begin{array}{c}0.9707 * * * \\
(0.0069)\end{array}$ & $\begin{array}{c}0.9708 * * * \\
(0.0069)\end{array}$ & $\begin{array}{c}0.9672 * * * \\
(0.0099)\end{array}$ & $\begin{array}{c}0.9211 * * * \\
(0.0026)\end{array}$ \\
\hline Tenure length $^{2}$ & $\begin{array}{c}0.9996 \\
(0.0003)\end{array}$ & $\begin{array}{c}0.9996 \\
(0.0002)\end{array}$ & $\begin{array}{c}1.0000 \\
(0.0003)\end{array}$ & $\begin{array}{c}1.0010^{* * *} \\
(0.0001)\end{array}$ \\
\hline Household head characteristics: & & & & \\
\hline Female & $\begin{array}{c}1.1099 * * * \\
(0.0259)\end{array}$ & $\begin{array}{c}1.11077^{* * *} \\
(0.0259)\end{array}$ & $\begin{array}{c}1.1516^{* * *} \\
(0.0550)\end{array}$ & $\begin{array}{c}1.1195^{* * *} \\
(0.0158)\end{array}$ \\
\hline Age & $\begin{array}{c}1.0437 * * * \\
(0.0128)\end{array}$ & $\begin{array}{c}1.0439 * * * \\
(0.0128)\end{array}$ & $\begin{array}{c}1.0294 \\
(0.0263)\end{array}$ & $\begin{array}{c}0.9243 * * * \\
(0.0044)\end{array}$ \\
\hline $\mathrm{Age}^{2}$ & $\begin{array}{c}0.9890 * * * \\
(0.0001)\end{array}$ & $\begin{array}{c}0.9990 * * * \\
(0.0001)\end{array}$ & $\begin{array}{c}0.9993 * * \\
(0.0003)\end{array}$ & $\begin{array}{c}1.0005^{* * *} \\
(0.0001)\end{array}$ \\
\hline
\end{tabular}




\begin{tabular}{|c|c|c|c|c|}
\hline Married & ref. & ref. & ref. & ref. \\
\hline \multirow[t]{2}{*}{ Single } & $0.8787 * * *$ & $0.8787^{* * *}$ & $0.7377^{* * *}$ & 1.0221 \\
\hline & $(0.0242)$ & $(0.0241)$ & $(0.0428)$ & $(0.0159)$ \\
\hline \multirow[t]{2}{*}{ Change to married } & $0.7987^{* * *}$ & $0.799 * * *$ & $0.6468^{* * *}$ & 0.9939 \\
\hline & $(0.0531)$ & $(0.0531)$ & $(0.1070)$ & $(0.0568)$ \\
\hline \multirow[t]{2}{*}{ Change to single } & $1.5968 * * *$ & $1.5977^{* * *}$ & $1.4769 * * *$ & $1.4500^{* * *}$ \\
\hline & $(0.0857)$ & $(0.0856)$ & $(0.1741)$ & $(0.0555)$ \\
\hline \multicolumn{5}{|c|}{$\begin{array}{l}\text { Job related variables (for the household } \\
\text { head): }\end{array}$} \\
\hline Employed & ref. & ref. & ref. & ref. \\
\hline \multirow[t]{2}{*}{ Out of workforce } & $1.4482 * * *$ & $1.4512^{* * *}$ & 1.1562 & 1.0238 \\
\hline & $(0.0704)$ & $(0.0701)$ & $(0.1223)$ & $(0.0199)$ \\
\hline \multirow[t]{2}{*}{ Change to employed } & $0.7644 * * *$ & $0.7653^{* * *}$ & $0.4488 * * *$ & $0.8483^{* * *}$ \\
\hline & $(0.0517)$ & $(0.0517)$ & $(0.0784)$ & $(0.0230)$ \\
\hline \multirow[t]{2}{*}{ Change to unemployed } & $1.7749 * * *$ & $1.7800 * * *$ & $1.4005 * * *$ & $1.3366 * * *$ \\
\hline & $(0.0660)$ & $(0.647)$ & $(0.1471)$ & $(0.0348)$ \\
\hline Non commuting & ref. & ref. & ref. & ref. \\
\hline \multirow{2}{*}{ Commuting } & $1.2999 * * *$ & $1.3052^{* * *}$ & $1.3396 * * *$ & $1.2105 * * *$ \\
\hline & $(0.0346)$ & $(0.0328)$ & $(0.0908)$ & $(0.0293)$ \\
\hline \multirow[t]{2}{*}{ Started to commute } & $1.9819 * * *$ & $1.9884^{* * *}$ & $2.2914 * * *$ & $2.0603 * * *$ \\
\hline & $(0.0909)$ & $(0.0898)$ & $(0.2305)$ & $(0.0853)$ \\
\hline \multirow[t]{2}{*}{ Stopped commuting } & 1.0775 & 1.081 & $1.3241^{* * *}$ & 1.0020 \\
\hline & $(0.0762)$ & $(0.0760)$ & $(0.1457)$ & $(0.0306)$ \\
\hline No education & ref. & ref. & ref. & ref. \\
\hline \multirow[t]{2}{*}{ Short education } & $1.0590 * *$ & $1.0582^{* *}$ & $1.1351^{* *}$ & $1.0500^{* * *}$ \\
\hline & $(0.0259)$ & $(0.0258)$ & $(0.0713)$ & $(0.0141)$ \\
\hline \multirow[t]{2}{*}{ Medium education } & $1.0902^{* *}$ & $1.0896 * *$ & $1.1804^{* *}$ & $1.0673^{* * *}$ \\
\hline & $(0.0387)$ & $(0.0383)$ & $(0.0899)$ & $(0.0195)$ \\
\hline \multirow[t]{2}{*}{ Long education } & $1.1654^{* * *}$ & $1.1671^{* * *}$ & $1.1161^{* * *}$ & $1.1156 * * *$ \\
\hline & $(0.0442)$ & $(0.0442)$ & $(0.1125)$ & $(0.0236)$ \\
\hline \multicolumn{5}{|l|}{ Housing characteristics: } \\
\hline \multirow[t]{2}{*}{ Persons per room } & $1.1277^{* *}$ & $1.1297^{* *}$ & $0.7309 * *$ & $1.6957 * * *$ \\
\hline & $(0.0680)$ & $(0.0681)$ & (0.0997) & $(0.0568)$ \\
\hline Single detached home (reference group) & ref. & ref. & ref. & ref. \\
\hline \multirow[t]{2}{*}{ Farm house } & $0.5290 * * *$ & $0.5287^{* * *}$ & $0.2999 * * *$ & $0.6475 * * *$ \\
\hline & $(0.0343)$ & $(0.0341)$ & $(0.0338)$ & $(0.0277)$ \\
\hline \multirow[t]{2}{*}{ Semi-detached home } & $1.5342^{* * *}$ & $1.5408^{* * *}$ & $1.3897 * * *$ & $1.2159 * * *$ \\
\hline & $(0.0462)$ & $(0.0470)$ & $(0.0857)$ & $(0.0322)$ \\
\hline \multirow[t]{2}{*}{ Multi-family housing } & $1.3415^{* * *}$ & $1.3447^{* * *}$ & 0.8525 & $1.2915^{* * *}$ \\
\hline & $(0.0988)$ & $(0.0992)$ & $(0.1020)$ & $(0.0400)$ \\
\hline City municipalities (reference group) & ref. & ref. & ref. & ref. \\
\hline \multirow[t]{2}{*}{ Suburb municipalities } & $0.8198^{* * *}$ & $0.8298^{* * *}$ & $0.8366 * * *$ & $1.1995^{* *}$ \\
\hline & $(0.0351)$ & $(0.0375)$ & $(0.0582)$ & $(0.0906)$ \\
\hline \multirow[t]{2}{*}{ Rural municipalities } & $0.8015^{* * *}$ & $0.7989 * * *$ & $0.7628 * * *$ & $1.2807 * * *$ \\
\hline & $(0.0385)$ & $(0.0383)$ & $(0.0553)$ & $(0.0894)$ \\
\hline \multirow[t]{2}{*}{ Remote municipalities } & $0.8721^{* * *}$ & $0.8692^{* *}$ & $0.7498^{* *}$ & $1.4246 * * *$ \\
\hline & $(0.0486)$ & $(0.0527)$ & $(0.0892)$ & $(0.0987)$ \\
\hline \multirow[t]{2}{*}{ Constant } & $0.0462^{* * *}$ & $0.0490^{* * *}$ & $0.0447 * * *$ & 1.1424 \\
\hline & $(0.0106)$ & $(0.0116)$ & $(0.0244)$ & $(0.1776)$ \\
\hline $\mathrm{N}$ & 510,093 & 510,093 & 125,172 & 820,128 \\
\hline McFadden's $\mathrm{R}^{2}$ & 0.17 & 0.17 & 0.22 & 0.25 \\
\hline
\end{tabular}

Table 3 repeats the analyses of Table 2, but now for the year 2005 when the Danish economy was on a steady positive growth path with increasing house values. The conventional control variables for migration are the same as in Table 2, but not shown in Table 3. The negative relations between high LTV ratios and the homeowners' mobility are fairly close to those found for the recession year 2009. We conclude that the relative lock-in effect of high LTV ratios is independent of the business cycle; but the absolute mobility level differs between the two economic climates. The propensity to move for tenants 
was, according to our estimates ${ }^{12}$, close to 0.13 in 2005 against 0.07 in 2009 . The most solvent homeowners had a 0.06 propensity to move in 2005 against 0.02 in 2009 . Homeowners with an LTV ratio above 1.2 had a propensity to move equal to 0.01 in 2005 against 0.004 in 2009. In both years, the mobility of homeowners with an LTV ratio above 1.2 was less than one fifth of the mobility of the most solvent homeowners.

Table 3: Logistic regression results for moving in the year 2005

\begin{tabular}{|c|c|c|c|c|}
\hline & $\begin{array}{l}\text { Only owners } \\
\text { (1) }\end{array}$ & $\begin{array}{l}\text { Price change } \\
\text { included } \\
\text { (2) }\end{array}$ & $\begin{array}{l}\text { Only most solvent } \\
\text { owners } \\
\text { (3) }\end{array}$ & $\begin{array}{l}\text { Tenants as } \\
\text { reference } \\
\text { (4) }\end{array}$ \\
\hline \multicolumn{5}{|l|}{ Categorical LTV dummies: } \\
\hline Tenants (reference group for column 4) & & & & ref. \\
\hline$[0,0.39)$ (reference group for column $1+2)$ & ref. & ref. & & $\begin{array}{c}0.4372^{* * *} \\
(0.0175)\end{array}$ \\
\hline$[0.39,0.79)$ & $\begin{array}{c}0.8713^{* * *} \\
(0.0198)\end{array}$ & $\begin{array}{c}0.8713^{* * *} \\
(0.0198)\end{array}$ & & $\begin{array}{c}0.3380 * * * \\
(0.0107)\end{array}$ \\
\hline$[0.8,0.99)$ & $\begin{array}{c}0.4648^{* * *} \\
(0.0196)\end{array}$ & $\begin{array}{c}0.4642^{* * *} \\
(0.0195)\end{array}$ & & $\begin{array}{c}0.1630 * * * \\
(0.0077)\end{array}$ \\
\hline$[1.0,1.19)$ & $\begin{array}{c}0.2312^{* * *} \\
(0.0145)\end{array}$ & $\begin{array}{c}0.2308^{* * *} \\
(0.0145)\end{array}$ & & $\begin{array}{c}0.0797 * * * \\
(0.0052)\end{array}$ \\
\hline$[1.2, \max )$ & $\begin{array}{c}0.2236 * * * \\
(0.0194)\end{array}$ & $\begin{array}{c}0.2231 * * * \\
(0.0193)\end{array}$ & & $\begin{array}{c}0.0763^{* * *} \\
(0.0068) \\
\end{array}$ \\
\hline Price changes below minus 5 pc. & & $\begin{array}{c}1.0375 \\
(0.0701)\end{array}$ & $\begin{array}{c}0.8604 \\
(0.1503)\end{array}$ & \\
\hline Price changes between minus 5 and plus 5 pc. & & ref. & ref. & \\
\hline Price changes above plus $5 \mathrm{pc}$. & & $\begin{array}{l}0.09708 \\
(0.0286)\end{array}$ & $\begin{array}{c}1.0023 \\
(0.0559)\end{array}$ & \\
\hline $\mathrm{N}$ & 528,897 & 528,897 & 151,157 & 851,498 \\
\hline McFadden's $\mathrm{R}^{2}$ & 0.07 & 0.07 & 0.12 & 0.16 \\
\hline
\end{tabular}

The regressions in columns (2) and (3) in Table 3 are better than the similar regressions in Table 2 to detect an association between loss aversion and mobility because of wider variation of housing price changes. In some municipalities, housing prices went down from 2004 to 2005 in spite of the positive trend for the country as a whole. With price changes between minus and plus five as reference, Table 3 shows coefficients for both negative and positive price changes. However, no significant association between price changes and mobility is found, and the propensity to move compared to the refence "turns around" between columns (2) and (3). We conclude that no lock-in effect because of nominal loss aversion can be detected.

Chan (2001), Engelhardt (2003) use the initial LTV ratio to reveal the households' innate mobility and Ermisch and Washbrook (2012) consider divorce and child bearing as endogenous. In general, we cannot expect any analysis to be completely free of from bias because of endogeneity, missing variables and self-selection. Homeowners will differ with respect to innate mobility and we have not captured these

\footnotetext{
12 The propensities reported here are calculated at mean values for other predicting variables. They are the (marginal) probabilities of a move.
} 
differences fully with our available control variables. But a natural experiment on a reduced sample may improve the reliability of our results.

\section{A "natural experiment"}

The established correlations in Table 2 and 3 between the propensity to move and the LTV ratio do not by themselves imply causality from the LTV ratio to the mobility of households. It could be that steady households borrow the most and so have high LTV ratios. If so, no lock-in effect from high LTV ratios is demonstrated. Instead, the LTV ratio becomes a measure of the innate steadiness of households. In a controlled experiment, households should have the same innate propensity to move and be randomly exposed to different LTV rations.

We employ the following procedure to perform a "natural experiment" that mimics the ideal. The households' predicted propensity to move in 2005 is calculated from the regression in column (1) in Table 3. A sample of the households with a predicted propensity to move within a specific range is then picked, and from this only households with an LTV ratio in a specific band are included. This is our "homogenous" sample of households. We assume that these households where unable to predict the future development of housing prices in their municipality from 2005 to 2009, i.e. their location in 2005 is independent of the LTV ratio in 2009. Statistic Denmark's SPAR price index illustrated in figure 1 show that housing prices increased steeply from 2005 to 2007 and then dropped dramatically with the resulting price change between 2005 and 2009 being modest. Our SPAR calculated prices show a drop of housing prices in 27 municipalities over this period, and price increases in 71 municipalities. The households are thus assumed to be randomly exposed to different LTV ratios in 2009. To secure that the movement of the LTV ratio is dominated by (the random) price developments, households with increasing mortgage debt over the period are excluded ${ }^{13}$ and we exclude households with a drop in their mortgage debt above 30 per cent from 2005 to 2009. The same is done for households where the value of the home falls or increases by more than 50 per cent over the period. Finally, only households where the household head has kept the same address over the years from 2005 to the entrance of 2009 are included.

There is a tradeoff between homogeneity of the households in the sample and the number of observations. More narrow bands for the predicted propensity to move and the LTV ratio increase the homogeneity and reduce the number of observations. Table 4 shows two set of bands and column (1) and (3) include changes in relevant control variables between 2008 and 2009 while column (2) and (4) includes changes in these variables over the period 2005 to 2009.

\footnotetext{
${ }^{13}$ There was an increase in the mortgage interest rate between the end of 2004 and the end of 2008, which meant that the market values of mortgage debt dropped over that period. Unchanged value of a household's mortgage debt can thus include a minor increase of the nominal debt.
} 
Table 4: Logistic regression results for homeowners moving in the year 2009 based on a natural experiment

\begin{tabular}{|c|c|c|c|c|}
\hline $\begin{array}{l}\text { Predicted propensity to move } 2005 \\
\text { LTV ratio } 2005\end{array}$ & $\begin{array}{l}2008-2009 \text { control } \\
\text { variables } \\
\text { (1) }\end{array}$ & $\begin{array}{l}2005-2009 \text { control } \\
\text { variables } \\
(2)\end{array}$ & $\begin{array}{l}\text { 2008-2009 control } \\
\text { variables } \\
\text { (3) }\end{array}$ & $\begin{array}{l}\text { 2005-2009 control } \\
\text { variables } \\
\text { (4) }\end{array}$ \\
\hline \multicolumn{5}{|l|}{ Categorical LTV dummies 2009: } \\
\hline$[0,0.79)$ (reference group) & ref. & ref. & ref. & ref. \\
\hline$[0.8,0.99)$ & $\begin{array}{l}0.5458^{* * *} \\
(0.1095)\end{array}$ & $\begin{array}{l}0.5696 * * * \\
(0.1194)\end{array}$ & $\begin{array}{c}0.5734^{* *} \\
(0.1370)\end{array}$ & $\begin{array}{c}0.6025^{* *} \\
(0.1513)\end{array}$ \\
\hline$[1.0, \max )$ & $\begin{array}{c}0.3162^{* *} \\
(0.1899)\end{array}$ & $\begin{array}{c}0.3307^{* *} \\
(0.2060)\end{array}$ & $\begin{array}{l}0.2231^{*} \\
(0.2009)\end{array}$ & $\begin{array}{l}0.2037^{*} \\
(0.1731)\end{array}$ \\
\hline $\mathrm{N}$ & 7532 & 7553 & 7580 & 7753 \\
\hline McFadden's $\mathrm{R}^{2}$ & 0.24 & 0.14 & 0.21 & 0.13 \\
\hline
\end{tabular}

There are fewer LTV intervals in Table 4 than in Table 2 and 3 in order to get better test statistic with a reduced number of observations. The reference is a LTV ratio below 0.8 , i.e. below the upper limit for borrowing from Danish mortgage banks. An LTV ratio above 0.8 is thus expected to give a lock-in effect and this effect should be stronger when the home is under water. Regressions with various bands for the predicted propensity to move and the LTV ratio have been run with fairly similar results, but with different degrees of significance. The results from two of those are shown in Table 4 . The regression in column (1) in Table 2 run with the same LTV intervals as in Table 4 gives the coefficient 0.5352 for the LTV ratio $=0.80$ to 0.99 and 0.2557 for the LTV ratio $=1.0$ to max. Judged by the results presented in Table 4 there may thus be a slightly weaker lock-in effect for a LTV ratio in the band 0.80 to 0.99 in our natural experiment setting ${ }^{14}$. No such tendency is found for the LTV ratio $=1.00$ to max. We infer that the results in our natural experiments do not deviate in any consistent way from the full population results and conclude that there is a lock-in effect from an LTV ratio above 0.8 and an even stronger effect when the housing equity becomes negative.

\section{Commuting}

Economists, city planners, engineers and environmentalists all have shown interest in commuting between the home and the workplace. Transportation economics is a subject of its own. Economists have been occupied with households' location and commuting choice and its relation with gender income, the choice of mean of transport, and the existence of excess and wasteful commuting. We abstain here from a literature review of the waste subject. A recent overview with emphasis on environmental aspects of transportation is Dargay (2008). Watts (2009) focus on the design of the cityscape and its influence on commuting, while e.g. Madden and Chiu (1990) looks at households'

\footnotetext{
${ }^{14}$ Regressions with other bands for the predicted propensity and the LTV ratio than the ones shown in table 4 can give coefficients below 0.5352 for LTV ratio $=0.80$ to 0.99 .
} 
location choice, commuting and the impact on women's wage. To our knowledge, no paper has connected commuting with the homeowners' LTV ratio. A paper of some interest is Immergluck (2010) who uses the per cent of auto commuters as a proxy for "commuting efficiency" of a city and regress the number of foreclosed homes over the years 2006 to 2008 in US metropolitan statistical areas on a number of variables. He finds no relation between commuting and foreclosures.

Based on Danish administrative data it has been shown by Munch et al. (2006 and 2008) that homeownership improves the probability for finding local jobs and that homeowners stay longer in their jobs. But it is still so, that a lock-in effect on homeowners from high LTV ratios can reduce the productive capacity of an economy and that part of this effect can be mitigated if homeowners with high LTV ratios commute more than homeowners not caught in an equity lock-in. With reference to the model in section three, commuting can increase a locked-in homeowner's welfare compared to non-commuting because commuting increases the employment possibilities and the expected household income.

We classify a household head as commuting when the municipality of the working place differs from the municipality where the home is located and analyze the propensity to commute for households who did not move in 2005 and 2009. The place of work observations are from the last week of November ${ }^{15}$ while most other information is obtained from the December 31 of the year or January 1 of the next year.

Table 5 gives the results of logistic regressions for the years 2005 and 2009 for non-moving households. Non-moving households may have a propensity to commute that is different from the commuting propensity of moving households. Our results can thus be expected to be biased when we are looking for the propensity to commute for all home owning households. Section nine shed more light on this, where we ask whether or not LTV locked-in and thus non-moving households obtain relatively high labor market mobility by commuting.

Table 5: Logistic regression results for commuting among non-moving households in the years 2005 and 2009

\begin{tabular}{|c|c|c|}
\hline & $\begin{array}{c}2005 \\
(1)\end{array}$ & $\begin{array}{c}2009 \\
(2)\end{array}$ \\
\hline $\begin{array}{l}\text { Tenants } \\
\text { Categorical LTV dummies: }\end{array}$ & ref. & ref. \\
\hline$[0,0.39)$ & $\begin{array}{c}1.1035 \\
(0.0724)\end{array}$ & $\begin{array}{c}0.9461 \\
(0.0807)\end{array}$ \\
\hline$[0.39,0.79)$ & $\begin{array}{c}1.1118 \\
(0.0976)\end{array}$ & $\begin{array}{c}1.0530 \\
(0.0956)\end{array}$ \\
\hline$[0.8,0.99)$ & $\begin{array}{c}1.1388 \\
(0.1312)\end{array}$ & $\begin{array}{c}1.2614^{* * *} \\
(0.1038)\end{array}$ \\
\hline$[1.0,1.19)$ & $\begin{array}{l}1.2080^{*} \\
(0.1318)\end{array}$ & $\begin{array}{c}1.4619 * * * \\
(0.1155)\end{array}$ \\
\hline$[1.2, \max )$ & $\begin{array}{c}1.1816 \\
(0.1330) \\
\end{array}$ & $\begin{array}{c}1.5299 * * * \\
(0.1218)\end{array}$ \\
\hline $\begin{array}{l}\text { Family related variables: } \\
\text { Household size }\end{array}$ & $0.9254 * * *$ & $0.9309 * * *$ \\
\hline
\end{tabular}




\begin{tabular}{|c|c|c|}
\hline & $(0.0164)$ & $(0.0064)$ \\
\hline \multirow[t]{2}{*}{ Increase in household size } & 1.0299* & $1.0365^{* *}$ \\
\hline & $(0.0164)$ & $(0.0153)$ \\
\hline \multirow[t]{2}{*}{ Decrease in household size } & $0.9426 * * *$ & $0.9290 * * *$ \\
\hline & $(0.0132)$ & $(0.0095)$ \\
\hline 1 household head income quartile (reference group) & ref. & ref. \\
\hline 2 household head income quartile & $\begin{array}{c}1.3900 * * * \\
(0.0323)\end{array}$ & $\begin{array}{c}1.4761^{* * *} \\
(0.0389)\end{array}$ \\
\hline 3 household head income quartile & $\begin{array}{c}2.0865 * * * \\
(0.0854)\end{array}$ & $\begin{array}{c}2.2096 * * * \\
(0.0949)\end{array}$ \\
\hline 4 household head income quartile & $\begin{array}{c}3.2684^{* * *} \\
(0.2263)\end{array}$ & $\begin{array}{c}3.4612^{* * *} \\
(0.2495)\end{array}$ \\
\hline A non-household head in the home has an income above 75.000 DKK & $\begin{array}{c}1.2054^{* * *} \\
(0.0181)\end{array}$ & $\begin{array}{c}1.1983 * * * \\
(0.0198)\end{array}$ \\
\hline High non-housing LTV & $\begin{array}{c}1.0738^{* * *} \\
(0.0160)\end{array}$ & $\begin{array}{c}1.1238^{* * *} \\
(0.0198)\end{array}$ \\
\hline Tenure length & $\begin{array}{c}0.9805^{* * *} \\
(0.0023)\end{array}$ & $\begin{array}{c}0.9852^{* * *} \\
(0.0026)\end{array}$ \\
\hline Tenure length $^{2}$ & $\begin{array}{c}1.0001^{* * *} \\
(0.0000)\end{array}$ & $\begin{array}{l}1.0000^{*} \\
(0.0000)\end{array}$ \\
\hline \multicolumn{3}{|l|}{ Household head characteristics: } \\
\hline Female & $\begin{array}{c}0.8181^{* * *} \\
(0.0207)\end{array}$ & $\begin{array}{c}0.8206 * * * \\
(0.0193)\end{array}$ \\
\hline Age & $\begin{array}{c}0.9960 \\
(0.0045)\end{array}$ & $\begin{array}{c}1.0013 \\
(0.0056)\end{array}$ \\
\hline $\mathrm{Age}^{2}$ & $\begin{array}{c}0.9999 \\
(0.0001)\end{array}$ & $\begin{array}{c}0.9999 \\
(0.0001)\end{array}$ \\
\hline Married & ref. & ref. \\
\hline Single & $\begin{array}{c}0.9430 * * * \\
(0.0115)\end{array}$ & $\begin{array}{c}0.9476 * * * \\
(0.0103)\end{array}$ \\
\hline Change to married & $\begin{array}{c}0.9772 \\
(0.0213)\end{array}$ & $\begin{array}{c}1.0270 \\
(0.0207)\end{array}$ \\
\hline Change to single & $\begin{array}{c}0.9431^{* * *} \\
(0.0213)\end{array}$ & $\begin{array}{c}0.9721 \\
(0.0251)\end{array}$ \\
\hline \multicolumn{3}{|l|}{ Job related variables (for the household head): } \\
\hline No education & ref. & ref. \\
\hline Short education & $\begin{array}{c}1.0174 \\
(0.0138)\end{array}$ & $\begin{array}{c}1.0042 \\
(0.0153)\end{array}$ \\
\hline Medium education & $\begin{array}{l}0.9355^{*} \\
(0.0325)\end{array}$ & $\begin{array}{c}0.8932^{* * *} \\
(0.0313)\end{array}$ \\
\hline Long education & $\begin{array}{c}1.2821^{* * *} \\
(0.1202)\end{array}$ & $\begin{array}{l}1.2064 * * \\
(0.1122)\end{array}$ \\
\hline \multicolumn{3}{|l|}{ Housing characteristics: } \\
\hline \multirow{2}{*}{$\begin{array}{l}\text { City municipalities (reference group) } \\
\text { Suburb municipalities }\end{array}$} & ref. & ref. \\
\hline & $\begin{array}{c}0.8455 \\
(0.2265)\end{array}$ & $\begin{array}{c}0.9356 \\
(0.2456)\end{array}$ \\
\hline Rural municipalities & $\begin{array}{l}0.5132^{* *} \\
(0.1369)\end{array}$ & $\begin{array}{r}0.5666^{* *} \\
(0.1507)\end{array}$ \\
\hline Remote municipalities & $\begin{array}{c}0.3481^{* * *} \\
(0.1035)\end{array}$ & $\begin{array}{c}0.3552^{* * *} \\
(0.1019)\end{array}$ \\
\hline Constant & $\begin{array}{l}0.8012 \\
(0.1586)\end{array}$ & $\begin{array}{l}0.6497^{*} \\
(0.1554)\end{array}$ \\
\hline $\mathrm{N}$ & 667,388 & 631,516 \\
\hline McFadden's $\mathrm{R}^{2}$ & 0.07 & 0.07 \\
\hline
\end{tabular}

The control variables used in Table 5 have signs in line with results presented in earlier studies, see Singell and Lillydahl (1986) and Rouwendal and Rietveld (1994). Higher income is associated with more commuting; two income households have high household head commuting, women commute less than 
men, and individuals with high educational attainment commute more. The low propensity to commute for people living in more remote areas is because remote municipalities cover bigger areas and this reduces the probability for crossing a municipal border on the home-to-work journey.

If there is a trend towards more commuting between the years 2005 and 2009 as figure 1 above demonstrates, e.g. because of improved infrastructure and an increased share of households with two income earners, this should be captured by use of appropriate control variables and the use of tenants as reference in the two years.

We expect homeowners to commute less than tenants given that homeownership is correlated with a high probability for finding local jobs according to Munch et al. (2008). However, the results reported in Table 5 do not support this expectation. In fact, repeating the regressions in Table 5 with tenants versus homeowners (leaving LTV ratios out) do not show a significant difference between owners' and tenants' propensity to commute. When we look at homeowners with different LTV ratios in the boom year 2005, see column (1), slightly higher propensities to commute appear for homeowners with negative equity, but a significant difference vis-à-vis tenants is not established. A reason for this could be that commuting in order to widen the search for employment is not that needed when the economy is booming and the demand for the labor is high. However, when the demand for labor is low as in the recession year 2009, see column (2), wider search for jobs is needed and a number of tenants as well as homeowners find jobs outside their present municipality and moves to where the jobs are. But locked-in homeowners with high LTV ratios cannot move and need to commute to enlarge the job search area. This explains the significant higher propensities to commute for those homeowners in the 2009.

The negative impact on labor market flexibility due to a lock-in effect on low equity homeowners will have stronger negative implications for the economy, when it is in recession and housing prices are falling. Our results show that part of this negative effect is mitigated by a comparatively high propensity to commute for locked-in homeowners in times when the demand for labor is low.

Our estimates show a commuting propensity of 0.38 for tenants in 2005 against 0.42 in $2009^{16}$. The commuting propensity for the most solvent homeowners was 0.41 in both 2005 and 2009. Among homeowners with an LTV ratio above 1.2, the propensity to commute was 0.42 in 2005 against 0.53 in 2009. Put in another way, the commuting propensity of the deepest under water households was 10 per cent higher than the commuting propensity for the most solvent households in 2005 . Under the recession in 2009 this difference reached 25 per cent. Under water homeowners increase their propensity to commute more than both homeowners with good solvency and tenants when the demand for labor is low.

${ }^{16}$ All the propensities are calculated at mean values for predicting variables. 
Table 6: Logistic regression results for commuting among non-moving homeowners in the year 2009 based on a natural experiment

\begin{tabular}{|c|c|c|c|c|}
\hline \multirow{3}{*}{$\begin{array}{l}\text { Predicted propensity to commute } 2005 \\
\text { LTV ratio } 2005\end{array}$} & \multirow{2}{*}{\multicolumn{2}{|c|}{$\begin{array}{l}0.40-0.60 \\
0.80-1.00\end{array}$}} & \multirow{2}{*}{\multicolumn{2}{|c|}{$\begin{array}{l}0.20-0.40 \\
0.80-1.00\end{array}$}} \\
\hline & & & & \\
\hline & $\begin{array}{c}2008-2009 \text { control } \\
\text { variables } \\
\text { (1) }\end{array}$ & $\begin{array}{c}2005-2009 \text { control } \\
\text { variables } \\
\text { (2) }\end{array}$ & $\begin{array}{c}2008-2009 \text { control } \\
\text { variables } \\
\text { (3) }\end{array}$ & $\begin{array}{c}2005-2009 \text { control } \\
\text { variables } \\
\text { (4) }\end{array}$ \\
\hline \multicolumn{5}{|l|}{ Categorical LTV dummies 2009: } \\
\hline$[0,0.79)$ (reference group) & ref. & ref. & ref. & ref. \\
\hline \multirow[t]{2}{*}{$0.8,0.99$} & $1.2972 * * *$ & $1.2949 * * *$ & 1.0448 & 1.0431 \\
\hline & $(0.1260)$ & $(0.1261)$ & $(0.0849)$ & $(0.0843)$ \\
\hline \multirow[t]{2}{*}{$1.0, \max$} & $1.7352^{* *}$ & $1.7192 * *$ & 1.0475 & 1.0464 \\
\hline & $(0.3894)$ & $(0.3934)$ & $(0.2074)$ & $(0.2089)$ \\
\hline $\mathrm{N}$ & 5135 & 5135 & 6082 & 6082 \\
\hline McFadden's $\mathrm{R}^{2}$ & 0.04 & 0.04 & 0.02 & 0.02 \\
\hline
\end{tabular}

A natural experiment along the lines explained in section 7 above is also done with the results presented in Table 6. Column (1) and (2) show that the propensity to commute is significantly higher for homeowners with an LTV ratio between 0.8 and 1.0 in 2005 when the sample is picked among those who have a predicted propensity to commute in the interval 0.4 to 0.6 . The causality from a high LTV ratio to a low mobility is thus corroborated by the experiment for this sample. But the result does not hold if the sample is picked among homeowners with a low predicted propensity to commute. There are however, reasonable explanations for this. A household head with low propensity to commute may be a woman having low income, being low educated, and living in a remote area. The woman (with children) will typically be closely connected to local kindergartens and schools, which should lead to intensified search for local jobs and acceptance of low wages; low income and low educated individuals will be closely associated with the local labor market where the pool of appropriate jobs is big; and living in a remote and comparatively wide municipality makes it less likely that commuting will involve the crossing of a municipal border. There may thus be groups of homeowners who have an especially strong attachment to local labor markets, and only few of such homeowners with negative equity will start to commute over municipal borders when the labor market tightens. But in general, the natural experiment setting does not lead us to change the conclusion that homeowners with high LTV ratios increase their labor market mobility through commuting in hard economic times.

\section{Joint decision on moving and commuting}

In a joint decision setting decisions for moving or not moving and commuting or not commuting can be combined in four different ways: a) not moving and not commuting, b) moving and not commuting, c) not moving and commuting and d) both moving and commuting. Table 7 contains results from a multinomial logistic regression for these combinations or states that a household can choose to be in after a year has passed in order to obtain maximum welfare. As 
before, we assume that the LTV ratio and other financial, family and housing characteristics affect the obtainable welfare from each state. The values of the explanatory variables are thus expected to predict the joint decision on moving and commuting that each household will make. Only the coefficients for the LTV categories are shown; the other explanatory variables included in the regression are as in Table 2 above, but with the commuting variables left out.

Table 7: The LTV ratio and four joint decisions on the household's state in a year's time 2009

\begin{tabular}{|c|c|c|c|}
\hline & $\begin{array}{l}\text { Moving \& } \\
\text { Not commuting }\end{array}$ & $\begin{array}{l}\text { Not moving \& } \\
\text { Commuting }\end{array}$ & $\begin{array}{l}\text { Moving \& } \\
\text { Commuting }\end{array}$ \\
\hline $\begin{array}{l}\text { Tenancy is reference } \\
\text { group } \\
\text { Categorical LTV dummies }\end{array}$ & - & - & - \\
\hline$[0,0.39)$ & $\begin{array}{l}0.3154 * * * \\
(0.0161)\end{array}$ & $\begin{array}{l}1.0745 \\
(0.0555)\end{array}$ & $\begin{array}{l}0.3728 * * * \\
(0.0245)\end{array}$ \\
\hline$[0.39,0.79)$ & $\begin{array}{l}0.2931 * * * \\
(0.0108)\end{array}$ & $\begin{array}{l}1.1948 * * * \\
(0.0570)\end{array}$ & $\begin{array}{l}0.3486^{* * *} \\
(0.0198)\end{array}$ \\
\hline$[0.8,0.99)$ & $\begin{array}{l}0.1453^{* * * *} \\
(0.0082)\end{array}$ & $\begin{array}{l}1.4066 * * * \\
(0.0623)\end{array}$ & $\begin{array}{l}0.2036 * * * \\
(0.0163)\end{array}$ \\
\hline$[1.0,1.19)$ & $\begin{array}{l}0.0734 * * * \\
(0.0072)\end{array}$ & $\begin{array}{l}1.5971 * * * \\
(0.0812)\end{array}$ & $\begin{array}{l}0.1055^{* * *} \\
(0.0121)\end{array}$ \\
\hline$[1.2, \max )$ & $\begin{array}{l}0.0685^{* * *} \\
(0.0070) \\
\end{array}$ & $\begin{array}{l}1.6675^{* * *} \\
(0.0901) \\
\end{array}$ & $\begin{array}{l}0.0683^{* * *} \\
(0.0099) \\
\end{array}$ \\
\hline $\mathrm{N}$ & 756,263 & & \\
\hline McFadden's $\mathrm{R}^{2}$ & 0.21 & & \\
\hline
\end{tabular}

The table reports the relative risk ratio that is the probability of each of the three combinations of moving and commuting states relative to the omitted base category of not moving and not commuting. The first column shows, that the risk for moving \& not commuting relative to not moving \& and not commuting is expected to decrease the higher is the LTV ratio, e.g. if the household falls into the highest LTV category, then the relative risk is reduced by a factor 0.07 , which means that the household is much more likely to be in the state of not moving \& not commuting than in the state of moving \& not commuting. The same is true for the state of moving \& commuting, as the relative risk for being in this state compared to the basis state also is reduced substantially. 
On the other hand, households with negative equity have much more higher relative risk of falling in the state of not moving \& commuting as compared to the basis state of not moving \& not commuting.

Table 8 shows the average probabilities, which is easier to interpret, for being in the three alternative mobility states and in each LTV category. The probability for moving is low for households with high LTV ratios; and heads of staying households with high LTV ratios have a comparatively high probability for commuting. Looking at homeowners alone, the drop of residential mobility from the most solvent to the most deeply under water households is from 2.5 to 0.5 percent, a fall of 2 percentage points in the state of moving \& not commuting and the drop for the state of moving \& commuting is from 1.3 to 0.2 , a fall of more than one percentage point. The corresponding increase of the probability for commuting among the heads of staying households is from 31.6 to 40.6 per cent or 9 percentage points.

Table 8: The LTV ratio and the average probability of three alternative mobility states, 2009

\begin{tabular}{clll}
\hline \hline & $\begin{array}{l}\text { Moving \& } \\
\text { Not commuting }\end{array}$ & $\begin{array}{l}\text { Not moving \& } \\
\text { Commuting }\end{array}$ & $\begin{array}{l}\text { Moving \& } \\
\text { Commuting }\end{array}$ \\
\hline Tenants & 0.0679 & 0.2860 & 0.0301 \\
& $(0.0026)$ & $(0.0180)$ & $(0.0014)$ \\
\hline Categorical LTV dummies & & & \\
{$[0,0.39)$} & 0.0253 & 0.3159 & 0.0128 \\
& $(0.0013)$ & $(0.0204)$ & $(0.0007)$ \\
{$[0.39,0.79)$} & 0.0232 & 0.3357 & 0.0116 \\
& $(0.0011)$ & $(0.0201)$ & $(0.0005)$ \\
{$[0.8,0.99)$} & 0.0116 & 0.3706 & 0.0065 \\
& $(0.0001)$ & $(0.0194)$ & $(0.0004)$ \\
& 0.0059 & 0.3971 & 0.0033 \\
& $(0.0001)$ & $(0.0121)$ & $(0.0003)$ \\
& 0.0055 & 0.4058 & 0.0021 \\
& $(0.0005)$ & $(0.0162)$ & $(0.0003)$ \\
\hline $\mathrm{N}$ & 756,273 & & \\
\hline Notes: Standard errors in parentheses is calculated using the delta method & & \\
& & &
\end{tabular}

The results for the relation between the LTV ratio and residential mobility from the multinomial model support our results above and the findings of most other authors. Homeowners' residential mobility on the labor market is negatively affected by a lock-in effect from high LTV ratios. Novel from our analysis is that homeowners' commuting pattern mitigates the effect from the equity lock-in on residential mobility. Locked-in homeowners commute more when 
the labor market is tight with few job opportunities, and wider job search is required to maintain a high degree of mobility on the labor market.

\section{Conclusions}

In this paper, we have tested the hypothesis that low housing equity reduces residential mobility and increases commuting. The study draws on Danish administrative register data with universal coverage and high reliability. The empirical analysis was carried out using simple logistic modeling with a binary outcome variable indicating whether a household has moved/do commute or not. Besides the LTV ratio we have a variety of family, job and housing related control variables traditionally thought to be mobility triggers. Our results confirm the negative relation between homeowners' LTV ratio and their mobility found by other authors. Furthermore, the relative lock-in effect of high LTV ratios seems to be fairly independent of the business cycle, but the absolute mobility differs. Both in 2005 and 2009, the mobility of homeowners with an LTV ratio above 1.2 is less than one fifth of the mobility of the most solvent homeowners. As a robustness check we have used the financial crisis in a natural experiment setting and analyzed the propensity to move/commute for homeowners of similar predicted propensity to move/commute and LTV ratios, when they are randomly exposed to different LTV ratio developments. We have also performed joined decision analysis on the different states of moving and commuting. The results of these robustness checks do not deviate from our first logistic regressions on the full population.

Homeowners are not found to commute less than tenants to workplaces located in other municipalities. Neither can a significant higher commuting propensity be established for homeowners with high LTV ratios when the economy is on a stable growth path. But this changes when the economy is slumping and the labor market becomes tight. Our results show that the commuting fraction of homeowners was 10 per cent higher for the deepest under water households than for the most solvent households under the prosperous economic climate in 2005. This difference increased to 25 per cent during the recession in 2009.

\section{References}

Abildgren, K., Drejer, P. A., \& Kuchler, A. (2014). Banks' loan rejection rates and the creditworthiness of the banks' corporate customers. Nationalokonomisk Tidsskrift, 151(2), 207-224.

Andersson , F. \& Mayock, T. (2014). How Does Home Equity Affect Mobility? Journal of Urban Economics, 84(1): 23-39.

Chan, S. (2001). Spatial lock-in: Do falling house prices constrain residential mobility? Journal of Urban Economics, 49(3), 567-586. 
Coulson, N. E. \& Grieco, P. L. E. (2013). Mobility and Mortgages: Evidence from the PSID. Regional Science and Urban Economics, 43(1): 1-7.

Dargay, Joyce (2008), "Personal Transport Choice", OECD Journal: General Papers, Vol. 2008/2. http://dx.doi.org/10.1787/gen_papers-v2008-art11-en

Donovan, C. \& Schnure, C. (2011). Locked in the House: Do Underwater Mortgages Reduce Labor Market Mobility? August. Working paper available at http://ssrn.com/abstract=1856073.

Engelhardt, G. V. (2003). Nominal loss aversion, housing equity constraints, and household mobility: evidence from the United States. Journal of Urban Economics, 53(1): 171-195.

Ermisch, J. \& Washbrook, E. (2012). Residential Mobility: Wealth, Demographic and Housing Market Effects. Scottish Journal of Political Economy, 59(5):483-499.

Ferreira, F., Gyourko, J., \& Tracy, J. (2010). Housing busts and household mobility. Journal of Urban Economics, 68(1): 34-4.

Green, R. K., \& Hendershott, P. H. (2001). Home-ownership and unemployment in the U.S. Urban Studies, 38(9), 1509-1520.

Henley, A. (1998). Residential Mobility, Housing Equity and the Labour Market. Economic Journal, 108(447), 414-427.

Immergluck, D. (2010). Neighborhoods in the wake of the debacle: Intrametropolitan patterns of foreclosed properties. Urban Affairs Review, 46(1), 3-36.

Madden, J. F., \& Chiu, L. C. (1990). The wage effects of residential location and commuting constraints on employed married women. Urban Studies, 27(3), 353-369.

Modestino, A. S., \& Dennet, J. (2013). Are American homeowners locked into their houses? The impact of housing market conditions on state-to-state migration. Regional Science and Urban Economics, 43: 322-337.

Munch, J. R., \& Svarer, M. (2002). Rent control and tenancy duration. Journal of Urban Economics, 52(3), 542-560.

Munch, J. R., Rosholm, M., \& Svarer, M. (2006). Are homeowners really more unemployed? Economic Journal, 116(514), 991-1013.

Munch, J. R., Rosholm, M., \& Svarer, M. (2008). Home ownership, job duration, and wages. Journal of Urban Economics, 63(1), 130-145.

Nickell, S. (1998). Unemployment: Questions and some answers. Economic Journal, 108(448), 802-816.

Nielsen, C. P. \& K. B. Jensen (2011). Declining Home Ownership among Young Danish Adults: An Affordability Problem or Just Postponement? AKF Working paper. AKF, Danish Institute of Governmental Research.

Oswald, A. (1996). A Conjecture on the Explanation for High Unemployment in the Industrial Nations: Part I. University of Warwick Working Paper (475). 
Rouwendal, J., \& Rietveld, P. (1994). Changes in commuting distances of Dutch households. Urban Studies, 31(9), 1545-1557.

Seko, M., Sumita, K. \& Naoi, M. (2012). Residential Mobility decisions in Japan: Effects of Housing Equity Constrints and Income Shocks under the Recourse Loan System. Journal of Real Estate Finance and Economics, 45(1): 63-87.

Skak, M., \& Bloze G. (2013). Danske Husholdninger på Dybt Vand, ( A study of loan to value ratios of Danish homeowners), report, University of Southern Denmark, online: http://www.bvc.dk/SiteCollectionDocuments/Analyser/Danske husholdninger paa dybt vand web.pd f

Schulhofer-Wohl, S. (2012). Negative equity does not reduce homeowners' mobility. Federal Reserve Bank of Minneapolis Quarterly Review, 35(1), 2-14.

Singell, L. D., \& Lillydahl, J. H. (1986). An empirical analysis of the commute to work patterns of males and females in two-earner households. Urban Studies, 23(2), 119-129.

van Leuvensteijn, M., \& Koning, P. (2004). The effect of home-ownership on labor mobility in the netherlands. Journal of Urban Economics, 55(3), 580-596.

\section{Appendix}

Table A.1: Descriptive statistics for the homeowners in the estimation samples

\begin{tabular}{|c|c|c|c|c|}
\hline & \multicolumn{2}{|c|}{2009} & \multicolumn{2}{|c|}{2005} \\
\hline & Mean & $\begin{array}{l}\text { Standard } \\
\text { deviation }\end{array}$ & Mean & $\begin{array}{l}\text { Standard } \\
\text { deviation }\end{array}$ \\
\hline \multicolumn{5}{|l|}{ Dependent variable: } \\
\hline Moving & 0.0205 & 0.1420 & 0.0478 & 0.2134 \\
\hline \multicolumn{5}{|l|}{ Independent variables: } \\
\hline LTV ratio & 0.6254 & 0.3457 & 0.5369 & 0.2890 \\
\hline Change of housing prices & -0.1381 & 0.0391 & 0.1722 & 0.0792 \\
\hline \multicolumn{5}{|l|}{ Family related variables: } \\
\hline Household size & 2.9891 & 1.2772 & 2.9642 & 1.2632 \\
\hline Increase in household size & 0.1049 & 0.3064 & 0.0609 & 0.2392 \\
\hline Decrease in household size & 0.1245 & 0.3301 & 0.0856 & 0.2803 \\
\hline Household's yearly income & 441,293 & 178,510 & 374,844 & 156,438 \\
\hline At least 20 per cent increase in income & 0.0935 & 0.2912 & 0.1214 & 0.3266 \\
\hline At least 20per cent decrease in income & 0.0730 & 0.2602 & 0.0608 & 0.2389 \\
\hline High non-housing LTV & 0.5171 & 0.4997 & 0.4454 & 0.4970 \\
\hline Tenure length & 11.7116 & 9.0812 & 12.058 & 9.5826 \\
\hline \multicolumn{5}{|l|}{ Household head characteristics: } \\
\hline Female & 0.2754 & 0.4467 & 0.2615 & 0.4394 \\
\hline Age & 44.0811 & 8.9019 & 43.8610 & 9.0701 \\
\hline Married & 0.6581 & 0.4744 & 0.6664 & 0.4715 \\
\hline Single & 0.3073 & 0.4614 & 0.2994 & 0.4580 \\
\hline
\end{tabular}




\begin{tabular}{|c|c|c|c|c|}
\hline Change to married & 0.0242 & 0.1538 & 0.0244 & 0.1542 \\
\hline Change to single & 0.0104 & 0.1013 & 0.0098 & 0.0988 \\
\hline \multicolumn{5}{|c|}{ Job related variables (for the household head): } \\
\hline Employed & 0.8911 & 0.3156 & 0.9205 & 0.2705 \\
\hline Out of workforce & 0.0323 & 0.1569 & 0.0327 & 0.1780 \\
\hline Change to employed & 0.0221 & 0.1471 & 0.0257 & 0.15825 \\
\hline Change to unemployed & 0.0545 & 0.2269 & 0.0210 & 0.1434 \\
\hline Commuting & 0.5372 & 0.4986 & 0.5497 & 0.4975 \\
\hline Not commuting & 0.3850 & 0.4866 & 0.3656 & 0.4816 \\
\hline Started to commute & 0.0464 & 0.2104 & 0.0477 & 0.2132 \\
\hline Stopped commuting & 0.0314 & 0.1744 & 0.0370 & 0.1887 \\
\hline No education & 0.2154 & 0.1111 & 0.2371 & 0.4256 \\
\hline Short education & 0.5309 & 0.4990 & 0.5291 & 0.4992 \\
\hline Medium education & 0.1591 & 0.3657 & 0.1534 & 0.3604 \\
\hline Long education & 0.0945 & 0.2926 & 0.0800 & 0.2712 \\
\hline \multicolumn{5}{|l|}{ Housing related variables: } \\
\hline Persons per room & 0.6551 & 0.3134 & 0.6583 & 0.3142 \\
\hline Single family house & 0.8249 & 0.3801 & 0.8192 & 0.3848 \\
\hline Farmhouse & 0.0627 & 0.2426 & 0.0677 & 0.2512 \\
\hline Semi-detached house & 0.0975 & 0.2966 & 0.0965 & 0.2954 \\
\hline Multi-family housing & 0.0148 & 0.1211 & 0.0165 & 0.1274 \\
\hline City municipalities & 0.3477 & 0.4745 & 0.3601 & 0.4800 \\
\hline Suburb municipalities & 0.1902 & 0.3966 & 0.1858 & 0.3890 \\
\hline Rural municipalities & 0.3480 & 0.4771 & 0.3433 & 0.4748 \\
\hline Remote municipalities & 0.1143 & 0.3181 & 0.1108 & 0.3139 \\
\hline Observations homeowners & 510,093 & & 528,897 & \\
\hline
\end{tabular}

Notes: Change variables are from 2008 to 2009 and from 2004 to 2005. 